\title{
In Memoriam: Waun Ki Hong, M.D. (August 13, 1942-January 2, 2019)
}

\section{Dr. Waun Ki Hong passed away on January 2, 2019.}

'Dr. Hong was born in Korea in 1942. He graduated from Yonsei University School of Medicine in 1967. After completing his 3 years of military service in the Korean Air Force, he went to the US and finished his internship and residency of internal medicine at the Bronx / Lebanon Hospital in NY City and at the VA Medical Center in Boston respectively. Dr. Hong served a two-year medical oncology fellowship at the Memorial Sloan Kettering Cancer Center in NY, then he returned to Boston as Chief of Medical Oncology of the VA Medical Center. During his nine-year tenure, he started his lifelong mission, which was translational and clinical cancer research in head and neck, and lung cancers. In 1984, Dr. Hong joined the MD Anderson Cancer Center in Houston as Chief of the Section of Thoracic, Head and Neck Medical Oncology and stepped down in 2005. He became head of the Division of Cancer Medicine from 2001 until he retired in 2014.

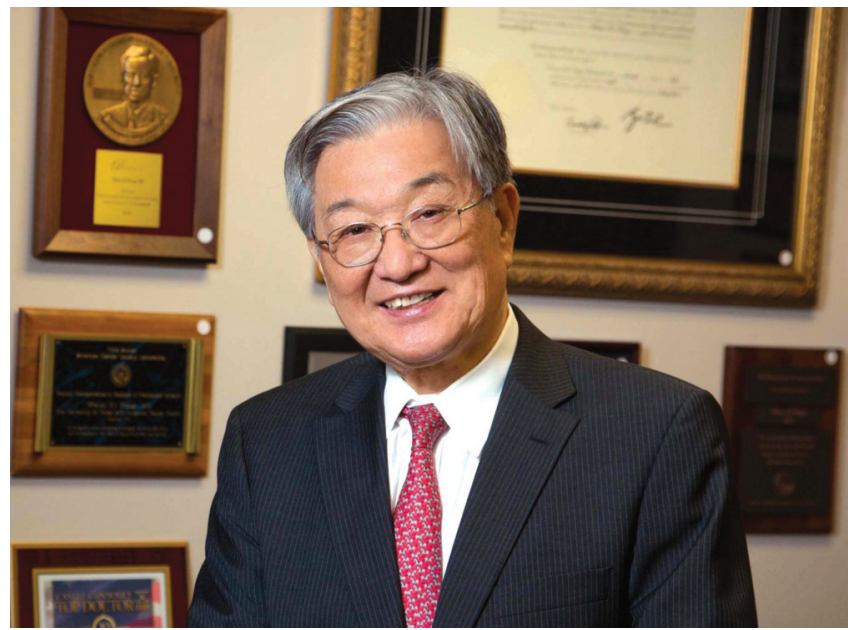

As chief of medical oncology at the Boston VA Medical Center in the early 1980s, Dr. Hong led a series of landmark clinical trials. He showed that chemotherapy and radiotherapy were effective alternatives to preserve the patient's voice box when they were being treated for laryngeal cancer. That discovery dramatically improved the quality of life for patients with this cancer and helped lay a foundation for organ preservation in numerous other cancers. Known as the father of chemoprevention, Dr. Hong conducted a clinical trial at MD Anderson Cancer Center to treat precancerous lesions for oral cancers. The clinical trial provided proof of principle for preventing cancer by treating its precursor growths, which led to new treatments for other organ sites, such as the use of taxomxifen and raloxifene to prevent breast cancer. Dr. Hong conceived and organized a unique clinical trial using biopsies to identify molecular targets in patients' tumors and then applied a matching therapy to the appropriate targeted molecules, which was a new field of therapy. He was the principal investigator of historical clinical trials, including the Biomarker-Based Approaches of Targeted Therapy for Lung Cancer Elimination (BATTLE). It showed that a personalized approach was not only feasible, but also highly promising, and provided the foundation for personalized targeted therapy. Precision medicine for lung and other cancers has been based on his research.

Dr. Hong was passionate about mentorship and many in the field benefitted greatly from his generous advice and help throughout the years. His mentorship of hundreds of clinicians has improved the quality of life for and extended the lives of many cancer patients all over the world.

Dr. Hong was elected American Association for Cancer Research (AACR) President, the first Asian ever elected, for the 20012002 term. During his presidency, he worked diligently to foster the field of cancer prevention, especially in precision cancer prevention, and to advance the field of translational cancer medicine. Dr. Hong was elected an Inaugural Fellow of the AACR Academy in 2013 and was honored with the AACR Margaret Foti Award for Leadership and Extraordinary Achievement in Cancer Research in 2016. In 2016, the AACR established the AACR Waun Ki Hong Award for Outstanding Achievement in Translational and Clinical Cancer Research. The award, which includes giving a presentation at the AACR Annual Meeting, is given internationally each year to a young researcher who has conducted significant translational or clinical cancer research.

He was a member of the National Academy of Medicine, a Fellow of the American College of Physicians, and held an American Cancer Society Clinical Research Professorship, a lifetime honor presented in recognition of his distinguished career. He served on major science and policy committees for the U.S. Food and Drug Administration, the National Cancer Institute, the 
National Cancer Advisory Board, and the President's Cancer Panel.

Among countless distinguished honors, Dr. Hong received the AACR-Richard and Hinda Rosenthal Foundation Award in 1993, the AACR Joseph H. Burchenal Award in 2000, the David A. Karnofsky Award from the American Society of Clinical Oncology in 2000, the Gold Medal of Paris from the International Congress on Anti-Cancer Treatment in 2001, the AACRCancer Research and Prevention Foundation Award for Excellence in Cancer Prevention Research in 2003, and the American Cancer Society Medal of Honor Award in 2012.

Dr. Hong was proud of Korea. He invited a hundred physicians and researchers to MD Anderson Cancer Center which gave them great time and opportunity to study there. Many of them became chairs or directors of cancer centers or leaders of cancer society in Korea.

Dr. Hong received an Expatriate Award from the Korean Broadcasting System in 1994, Ho-Am Prize in Medicine from the Samsung Foundation in 1994, Proud Korean Award from the Korean American Leadership Foundation in 2012, Proud Alumni Award from Yonsei University in 2014, and the Korean American Medical Association (KAMA) Lifetime Achievement Award in 2015. He was a member of the National Academy of Medicine in Korea.

Dr. Hong was an Advisory Member of National Cancer Center and a Chair of Advisory Committee of Yonsei Cancer Center Construction. He had attended annual meetings of the Korean Cancer Association as an invited speaker, and cheered Korean oncologists up to have a dream and passion. In 2018, he made it possible to have the AACR-KCA Joint Conference in Seoul, Korea where he gave a lecture entitled 'Precision Medicine in Lung Cancer: Opportunities and Challenges.' He talked about how he designed and conducted the BATTLE Trial and how he progressed to precision medicine. The lecture was educational and inspiring, even though it was the last lecture he gave in Korea.

Dr. Hong loved baseball, especially the Red Sox. He used to take his family to a winter camp in Miami, Florida to meet and watch players practicing. One time, Dr. Hong threw the first pitch at Fenway Park, which is the Red Sox's Ball Park. The City of Boston proclaimed May 22, 2015 to be Dr. Waun Ki Hong Day.

He liked to use the terms of baseball when he talked to his colleagues and trainees. "Don't try to hit a homerun at the start, but just go for a small hit." Dr. Hong asked them to study hard, for at least 18 hours a day as he did, and taught them how to start research. Once it starts, don't give up; as Dr. Hong would say, "The winning runner is still on base." He worked hard to get the runner home to win the game of cancer research.

The memorial service was held at Onnuri Church, Newport, California on January 12, 2019 to celebrate the life of Dr. Hong. Hundreds people from in land and abroad attended, and members of the Korean Cancer Association and Yonsei Medical Center were there. The memorial clearly shows how he was loved as a teacher, a friend and a colleague, and his love goes towards helping cancer patients that he never even met. He devoted his whole heart and life to improving cancer treatment, and he will live on in his research and in the lives his work touches.

In memory of mentor Dr. ‘曙園’ Waun Ki Hong,

Advisory Member, The Korean Cancer Association Hoon-Kyo Kim 